\title{
Israelization and Lived Religion: Conflicting Accounts of Contemporary Judaism
}

\author{
Adam S. Ferziger ${ }^{1}$ D \\ Received: 4 August 2019 / Accepted: 4 May 2020 / Published online: 2 June 2020 \\ (c) Springer Nature B.V. 2020
}

\begin{abstract}
The article begins with an analysis of Yossi Shain, Ha-Me'ah ha-Yisraelit ve-ha-Yisraelizaziyah shel ha-Yahadut (The Israeli Century and the Israelization of Judaism) (2019), which puts forward a novel and enlightening revisionist view of the relationship between Israeli and American Jewries. The second part of the article reveals essential problems with Shain's central argument. These come to a fore through the study of Judaism as a lived religion. Three examples are discussed at length to illustrate this point: developments in the religious lives of liberal Jews, Chabad, and Orthodox Feminism.
\end{abstract}

Keywords Israel · Israelization · Yossi Shain · Jewish world · Diaspora · Judaism • Religion · Lived religion · Charles Taylor · Yuri Slezkine · Chabad · Religious feminism $\cdot$ American Judaism

\footnotetext{
I am indebted to my colleagues in the "Religion and Secularization Research Group" at BarIlan University for the enlightening dialogue during our Spring 2019 meetings that inspired me to consider Yossi Shain's thesis through the prism of Charles Taylor's conceptualization. My initial findings were presented at the Sixth Annual Oxford Summer Institute on Modern and Contemporary Judaism, University of Oxford (July 2019). The final product was sharpened in light of the thoughtful and critical responses from the following colleagues who read earlier drafts: Judy Baumel-Schwartz, Jodi Eichler-Levine, Zev Eleff, Yoel Finkelman, Sara Hirschhorn, Hartley Lachter, David N. Myers, Yaacov Yadgar, and the editor and anonymous readers of Contemporary Jewry.
}

Adam S. Ferziger

ksferz@gmail.com

$1 \quad$ Bar-Ilan University, Ramat-Gan, Israel 
The complex interface between the State of Israel and Jewish life throughout the world has drawn considerable attention in the past few years. Numerous highpowered conferences have been held (Borschel-Dan 2018; Kraft 2019; Kustanowitz 2019), studies and books have appeared (D. Waxman 2016; Gordis 2019), ${ }^{1}$ and new organizations have been established with the express goal of addressing what has been deemed by many to be a growing "distancing" (Halutz 2015; Ravid 2018; Mlotek 2019; Tibon 2019). ${ }^{2}$ In the spring of 2019, a Hebrew book appeared that engages the underlying foundations of the contemporary relationship through a truly provocative "paradigm-changing" thesis.

Yossi Shain's Ha-Me'ah ha-Yisraelit ve-ha-Yisraelizaziyah shel ha-Yahadut (The Israeli Century and the Israelization of Judaism) (2019) puts forward a revisionist view that moves past the novel and jarring to the partially convincing. Deeper examination, as I will argue in the second part of this article, reveals essential problems with the author's central argument. Nonetheless, exposure to the fresh approach itself stimulates thinking and facilitates efforts to sharpen perceptions.

Shain, a Tel Aviv University political scientist who until recently held a concurrent appointment at Georgetown University in Washington DC (Rosner 2018), challenges the notion that Israel and the Diaspora are, as a well-regarded 1990 study emphasized, Two Worlds of Judaism (Liebman and Cohen 1990). Rather, he presents a picture of a Jewish globe with Israel at its center. His core claim is stated already on the first page of the monograph: "Since its establishment in 1948, the State of Israel has gradually situated itself as the most important factor in all areas of worldwide Jewish life.... The nation of Israel and Jewish civilization are defined today more than ever through the political, military, and cultural power of the sovereign Jewish state" (Shain 2019).

As the discussion moves forward, I will offer an alternative perspective to Shain's thesis through the prism of counter examples from the lived religion of contemporary Jews. The first part of the article, however, is devoted to a detailed explanation and examination of his core paradigm. To focus a comparative lens on Shain's unique viewpoint, as well as to set the stage for my subsequent analysis, I will begin with a brief foray into Charles Taylor's already-classic 2007 tome, A Secular Age (2007).

\section{A Secular Age; an Israeli Age}

Taylor's (2007) work addresses the ongoing academic debate over the degree to which the Western world has become secularized. Most previous discussions of the subject revolved primarily around demonstrating that secular ideals, forces, and institutions in the world were expanding and gaining greater acceptance while religious ones were declining. The deterministic understanding that

\footnotetext{
1 Already in 2010, an entire issue of Contemporary Jewry (2010) was devoted to the topic.

2 Full disclosure: My son is active in the Shazur/Interwoven organization, and I spoke at the Z3 Conference sponsored by the Oshman Family JCC in Palo Alto, California in November 2019.
} 
secularization was advancing in a linear fashion, highlighted in books such as Peter Berger's The Heretical Imperative (1979), was challenged by the resurgence of religious fundamentalism that characterized the 1980s and beyond. Indeed, Berger (1999) himself eventually offered a more nuanced interpretation in light of these upheavals. Taylor, in contrast, is more convinced than ever that the core of contemporary Western civilization is situated in the secular realm. The source for his position, however, is an account of the role of secularism in society that does not depend on the ups and downs of one side or the other. Alternatively, the key factor is what he calls "the conditions of belief" (Taylor 2007).

What distinguishes the current era, according to Taylor, is that regardless of one's own personal religious stance, in Western society the point of departure for how to perceive the world is the secular one. That is, on the one hand, scientific truths and ideal political structures that are completely independent of parochial authority and belief are taken for granted as the normative framework of society. On the other hand, acceptance of religious and spiritual ideals demands digressing from or denying that which is clear cut and assumed. This stands in contradistinction to previous times when the opposite was the case. Religious principles of belief and practice were the guiding paradigm, and individuals like Spinoza, who challenged these presumptions, were deviants. In the current condition, religion has not disappeared, nor, for the most part, has it been completely dismissed. Yet it is no longer the foundation of authority or truth. It is simply a choice, and far from the obvious one. As Taylor put it:

[T] he change I want to define and trace is one which takes us from a society in which it was virtually impossible not to believe in God, to one in which faith, even for the staunchest believer, is one human possibility among others....

Secularity in this sense is a matter of the whole context of understanding in which our moral, spiritual or religious experience and search takes place....

An age or society would then be secular or not, in virtue of the conditions of experience of and search for the spiritual. (Taylor 2007, 3)

Once this "presumption of unbelief" has become dominant, even those who continue to believe staunchly, according to Taylor, operate in a secular milieu.

Unlike Taylor's, Shain's book is not a work of philosophy. It combines a multidisciplinary examination of the contemporary Jewish world with a teleological metanarrative of Jewish history from ancient times that adumbrates his reading of current realities. It certainly addresses religious people and groups, but, as opposed to Taylor, he is not particularly interested in what is going on in the minds of believers and nonbelievers. Shain is a political scientist for whom what counts most of all is where the center of power sits. But power, as the book articulates, is not defined exclusively through military and economic strength nor political allegiance. Power is also about how a certain body, here the sovereign Jewish state, impacts upon the lives of others-especially Jews but not only.

Thus, there is a core analytical perspective that underlies both volumes. In parallel to Taylor's "conditions of belief," what characterizes the "Israeli century" is 
not that the State of Israel is incrementally achieving consensus among all Jews. The main change is that regardless of whether one lives in Israel or not, or identifies with the Zionist project or not, Israel has become the central issue around which both Jews and non-Jews worldwide engage Judaism. Israel is for twentyfirst century Jews what secular constructs are for most Western individuals: the foundational element that frames most other Jewish involvements, ideological positions, political activity, and cultural production. In point of fact, according to Shain, Israel is also the predominant factor in non-Jewish engagement with Judaism-again, for those whose relationship is positive as well as for those who are neutral, antagonistic, or seek to harm (Shain 2019).

\section{Israelization}

Shain is undoubtedly an ardent Zionist who celebrates the renaissance of Jewish political, military, and economic power, and the rise of a sui generis Israeli Jewish culture. Indeed, he maintains that it is becoming clear to most Jews that their personal security is dependent on a strong Israel. Nonetheless, unlike the founders of the State-many of whom negated Diaspora life and dedicated their efforts toward immigration (Schweid 1984)_or, for that matter, the eminent contemporary novelist A. B. Yehoshua (2006), Shain's is a global vision built around a robust Israeli center. American Jewry is undoubtedly still a rich and powerful Babylon; but the parallel phenomena of rising Israeli strength, heightened antisemitism, and radical assimilation have left it playing second fiddle. While no longer predicating its relationship to world Jewry on the hope that they will find their inner "Zerubabel" and take up the "Cyrus challenge" to return home, it is Israel, advances Shain, which sustains its distant kin to an ever-greater degree.

Israel's centrality to Jewish life, according to Shain, is reflected in its critical mass of Jews, destined within a few years to outgrow the rest of the world's Jewish population, and the diverse, hyper-creative, and multicultural Jewish environment that it has facilitated (DellaPergola 2018). Israeli academicians, writers, musicians, cinematographers, and "start-up-ists" have achieved a global footprint and nourish Jewish pride in communities across the planet (Senor and Singer 2009).

From an opposite point of view, the past few years have witnessed numerous examples of figures such as billionaire world Jewish leaders Charles Bronfman and Ronald Lauder, who have complained publicly that Israel is either insensitive or completely disregards the needs and ideals of Diaspora Jews. In May 2018, for instance, Bronfman declared the need to create a more intensive dialogue between Diaspora Jews and Israel:

But do Israelis care enough about what happens in the global Jewish World?.... Let's establish a permanent, serious lobby in Jerusalem including both Israeli and North American Jewish groups. The time has come to demonstrate both the negatives as well as the positives that proposed Israeli legislation will have on North American Jewry. At the same time, we must heighten awareness of 
our vibrant communities, their importance to Israel and their real need to be recognized as full partners. (Bronfman 2018)

For the most part, newspapers and pundits perceived this pronouncement as reflecting intensification of the "distancing" trend from Israel that has reversed in recent decades the "love affair" that characterized the post-1967 era. In Shain's eyes, however, such remonstrations-justified or not-reify the degree to which contemporary Jewish life revolves around and is dependent upon its Jerusalem center.

Israel is committed to protecting the lives of all Jews wherever they choose to live asserts Shain. Moreover, as opposed to North America, where due to assimilatory trends Jewish continuity is becoming tenuous, it is the State of Israel, where the nation feels rooted and secure in its national identity. This enables Jews to realize their globalizing talents without undermining their deep links to their singular tradition and culture "The deep sense that one has a home to return to enables them to traverse and engage the big world with ease and confidence" (Shain 2019, 14). Thus, the proliferation of expatriate Israelis who have settled in Silicon Valley, Southern Florida, and Berlin does not indicate a decline in the Zionist ideal. It is, rather, a testament to the fortitude and long-term stability of the Jewish state. These individuals generally maintain close ties with the "mother country." They follow news from "back home" vigilantly and serve as cultural agents who communicate "Israeliness" to their Diaspora brethren. Their successes are Israel's successes (Shain 2019).

Israel's own economic prowess, says Shain, combined with the increasing role of Israelis in North American Jewish life, have neutralized its former dependency on the "rich American uncle." If anything, there is a role reversal in which Israel provides a security blanket, not just on a physical level but for Diaspora Jewish identity. The preeminent example of this phenomenon is the Birthright (Taglit) program. Since its inception in the late 1990s, it has brought more than 600,000 young adults to Israel for ten days of intensive Israeli and Jewish immersion. In the eyes of Jewish leaders both in Israel and throughout the world, it is considered to be the most successful Jewish educational initiative of the past few decades and a key to fortifying Diaspora Jewish life (Kelner 2010; Abramson 2017; Shain 2019).

In parallel to those who turn to Israel for inspiration, a vocal and growing constituency of Diaspora Jews feels alienated from its power and nationalist orientation, especially as reflected in its policies toward Palestinians. For them, explains Shain (2019), this is the opposite of the universalist, humanitarian, tikkun olam-oriented Judaism upon which they were nurtured. ${ }^{3}$ Some protest or look for ways to strengthen Israeli groups that advance alternative approaches. A growing minority support boycott, divesture, and sanction (BDS) initiatives, aimed to punish Israel for its policies and pressure it to change them, and/or question the very legitimacy of a Jewish nation-state. On this conflict, Shain makes his opinion clear. While certainly opposed to unrestrained force when it can be avoided, in the Niebuhrian

\footnotetext{
${ }^{3}$ Gordis, in We Stand Divided (2019), focuses on the differences between the core existential ideals of Israeli and American Jewish life and the long history of this divide, but, in distinction from Shain, he does not present Israel at the center of the orbit of both Jewish worlds.
} 
debate between sovereignty and humanism, he chooses the former (Niebuhr 1932), not due to an all-out rejection of liberal values, but because from his view a state cannot function by the same rules as powerless individual Jews living under the control of others (Gordis 2019; Shain 2019). Yet in his scheme of Israelization, which is predicated - as emphasized above through the comparison with Taylor-on the "conditions of belief" rather than the belief itself, those Jews who are ambivalent about Israel or even adopt the other side completely are drafted to support his contention. Inasmuch as they protest their distaste or repulsion, it is Israel that drives their passion.

Here Shain leans on, among others, the work of Israeli literary scholar Gitit LevyPaz (Levy-Paz 2016), who has highlighted the propensity of contemporary American Jewish writers to place Israel and its foibles at the center of their novels. In the past decade, leading authors such as Michael Chabon, Nathan Englander, Nicole Krauss, and Jonathan Safran Foer have all published works that grapple with their ambivalence toward the Jewish state and its political and religious character. Chabon in particular is outspoken in his reproach of the Israeli government and produced a novel, The Yiddish Policemen's Union (2007), which renders a counter-history in which Israel actually never came into existence. In Shain's eyes, Chabon's “criticism manifests connection" (2019). He cites, as well, Englander's own testimony to the obsession with Israel of him and his American Jewish colleagues: "I really don't know what got into us...somehow Israel eats away at us. While it is difficult to compare my book to those of other friends in our Jewish mafia... among them too, Israel is in the background" (Shmilovitz 2018). Summing up the connection between these Jewish writers and Israelization, Shain declares: "[A]longside Israeli Hebrew literature, there is also literature being produced in the Diaspora that is characterized by its relationship to Israeli sovereignty. It is not written in Hebrew, nor in the territory of the motherland, but its focus is the Israeli century" (2019).

In the Israeli century, antisemitism has by no means disappeared. On the contrary, there is consensus that the last decade has witnessed a major uptick in public outbursts of Jew-hatred throughout the globe, and not just in European countries whose deeply-rooted phobias regarding Jews find strange bedfellows with some elements within Muslim constituencies-ironically themselves the victims of some of the same prejudices. Even in the United States, where Jews have felt especially safe, this is no longer necessarily the case, as the two murderous synagogue attacks of 2018 and 2019 in Pennsylvania and California revealed tragically (Pink 2019). Even though these remain isolated and unusual events, the ubiquitous police patrol cars and armed guards along with congregational volunteers in front of most large synagogues give visual expression to the sea-change in the rhythm of contemporary North American Jewish life.

Shain is fully aware that there are multiple factors that foster antisemitism. Yet he asserts that the critical distinction between contemporary trends and those of the past is the fusion by so many of anti-Israel attitudes with loathing of Jews. To be sure, non-Jewish anti-Israel activists - as well as Jews who are alienated from the State and cultivate cosmopolitan identities that are independent of, if not antagonistic to, Zionism-argue that anti-Zionism and antisemitism are dissimilar. All the same, as Shain emphasizes, such distinctions are not borne out by radical Muslim efforts to introduce 
classical tropes of antisemitism into the discourse of the current conflict (Litvak 2006), nor, as figures such as French-Jewish intellectuals Bernard-Henri Lévy (Efune 2015) and Alain Finkielkraut (2004) have argued, by other manifestations of public antisemitism throughout the world. Indeed, Shain gives his imprimatur to a term coined by others, the "Israelization of antisemitism" (2019).

Even more acutely than the conflation of anti-Israel attitudes with Jew-hatred, Shain's Israeli century is characterized by a transformation in the ways Jews respond to antisemitism, with the existence of Israel and the power that it wields being gamechangers on multiple levels. For example, in parallel to the antipathy that Israeli power has engendered, Israel possesses unprecedented tools for engaging enemies of the Jews. The Mossad intelligence agency, for example, has a division called "Bizur" that is charged with assisting Jewish communities throughout the world in protecting themselves. Its agents train local Jews in self-defense and surveillance. Since the 1990s, as described by Israeli investigative journalist Yossi Melman (Melman 2010), some of its alumni have also set up private companies in the West that specialize in providing solutions to congregational and communal security concerns (Shain 2019).

On another level, countries that in the past tolerated and even promoted antisemitism recognize today that there may be a price to pay in terms of their economic and diplomatic relations with Israel. To be sure, sometimes the Israeli government itself downplays anti-Jewish statements and policies in other countries in furtherance of diplomatic and economic interests. Notwithstanding, there are numerous examples that suggest that Israeli relations with such governments cause their leaders to hedge their populist, nationalist-oriented positions in order to prevent a strong Israeli backlash (Keinon 2017; Ahren 2019). What is clear in recent years, moreover, is that Arab regimes, such as Dubai, Bahrain, and even Saudi Arabia and Oman, which in the past downplayed or prohibited a public Jewish or Israeli local presence, have openly nurtured local Jewish communal life and opened their doors to Israelis (J. Ferziger and Odenheimer 2018). Here, Israel's economic and political assets have not only resulted in the Palestinian issue looming less large but have neutralized the confluence of antipathy to Israelis and Jews that once reigned. Just as historians asserted that the modern racial-oriented antisemitism that arose in the nineteenth century differed in fundamental ways from its medieval and ancient ancestors (J. Katz 1982), so too has antisemitism and responses to it been altered, in Shain's scheme, by the now-established and stable Israeli sovereign state.

Toward the end of the book, Shain shares some of his own concerns and criticisms regarding the post-1967 borders and current settlement policies. His core thesis, however, stands independent of these predilections. For, as he asserts throughout, regardless of whether one sympathizes with or strongly opposes specific Israeli policies or even Israel's existence, the crucial issue is that the "conditions" have changed. In the Israeli century, then, both anti-Judaism and Judaism itself have been transformed. 


\section{A Babylonian Legacy: Slezkine's Jewish Century}

The title of Shain's book alludes to University of California historian Yuri Slezkine's equally provocative 2004 work, The Jewish Century (2019, New Edition). Shain's work contains a critique and provides a stark alternative to the prior publication. By referencing Slezkine briefly, I seek to illustrate the degree to which these two monographs may be seen as representing the poles of the contemporary "Jerusalemian" versus "Babylonian" perceptions of Judaism (Rawidowicz 1957). That said, I will then point to a commonality between them that will serve as the foundation for my critique of Shain.

Slezkine also thinks about Jews in global terms. But unlike Shain, who celebrates the transformative impact of territoriality, sovereignty, and homeland for Jews both in Israel and outside it, Slezkine does just the opposite. He defines the Jews as the most successful example of "Mercurian" nations in history that functioned according to alternative patterns of existence from those of most territorially-based collectives, "specializing in the delivery of goods and services to the surrounding agricultural or pastoral societies" (Slezkine 2019, 7). The Mercurian groups share a common destiny of combining exceptional economic success with rousing antagonism and resentment in their hosts.

According to the Russian-born and trained Slezkine, due to their unusual talents, Jews have increasingly influenced the trajectory of the Western world. He presents the vital role of Jewish intellectuals and activists in the Bolshevik Revolution and the first decades of the Soviet Union as exemplary of the success, impact, and hostility associated with their "Mercurian" identity. As such, he argues that one of the boldest trends in modern history is the affirmation and adoption by others of the Jew's model of existence. As an ideal, modern identity means being "urban, mobile, literate, articulate, intellectually intricate, physically fastidious, and occupationally flexible" (Fox 2005). As Stephen Whitfield put it in a trenchant review, "for...Yuri Slezkine, the Jews are modernity-and everything in his flamboyant account of their fate over the past century follows from that equation" $(2006,316)$.

Slezkine admits that "Zionism prevailed over communism...because nationalism everywhere prevailed over socialism" $(2019,363)$. In the process, however, this "most eccentric of nationalisms," in which Jews tried to be like the rest of the world, sacrificed at the altar of sovereignty the authentic Mercurian characteristics that had made the Jews so successful in the early days of the Soviet Union. For it was the establishment of the State of Israel, he asserts, that reactivated government-sanctioned antisemitism in mid-twentieth century Stalinist Russia.

Despite the decline of the Jewish role in the Soviet Union, the parallel setting, capitalist America "the least revolutionary..._- proved the most successful" (Slezkine 2019, 367). In the United States, says Slezkine, they landed "in a country founded by Protestant Mercurians in the seventeenth and eighteenth centuries, and [could] take their place alongside all the other Mercurianized immigrant groups as part of a general celebration of American 'diversity' and 'ethnicity" (Lazare 2005). Thus, it is in the twenty-first century United States where the legacy of "The Jewish Century" continues to unfold. 
Shain too applauds the achievements of American Jewry throughout his book. However, he opines, their profound successes have also led to their demise as a cohesive collective: "All those characteristics that Slezkine projects as American Jewry's greatness, are the same ones that are incrementally causing its internal obliteration as a unique ethnic group" (Shain 2019, 14). Under these circumstances, Shain argues, "Its ongoing existence as a Jewish community is increasingly dependent on identification with the State of Israel and connection with it. It is the State of Israel, where the nation feels rooted and secure in its national identity, that enables Jews to realize their globalizing talents without undermining their deep links to their singular tradition and culture" (Ibid.).

\section{Political Religion}

Despite their diametrically opposed understandings of what constitutes Jewish impact and the importance of ethnic continuity, Slezkine and Shain share a common underlying approach as far as religion is concerned. Their core theses are predicated on a political perception of religion that highlights its macro-effect on collective life. Their principal concerns are not with theological or ideological content or spiritual movements onto themselves, and certainly not actual practice, but on how the social manifestations of these concepts may impact political and cultural structures. Slezkine says so explicitly. In an interview that took place after the 2017 publication of his book on the Russian Revolution, he attested:

All movements commonly known as "religions" are political. Pontius Pilate, whatever his private reservations, had good reasons for wanting Jesus out of the way. And who doubts the political nature and success of early Islam?

My own preference is to drop the word "religion" altogether. It impedes communication and blinds people to connections they would otherwise find illuminating. Can you think of a definition of "totalitarianism" that would not apply to Christianity, Islam...? The fixation on the need to keep "religions" separate is the only reason most scholars consider Nazism and Bolshevism bizarre modern inventions. (Slezkine et al. 2018)

Shain is not averse to the term religion nor to engaging parochial matters. Parsing the role of religion in his work, therefore, is more complicated. Yet a review of his discussions of religion within the book demonstrates that he too perceives it primarily in political terms.

In parallel to dismissing the transformation by Slezkine and others of the wandering Jew into a romanticized ultimate cosmopolitan modern, Shain acknowledges the potency of certain religious motifs during various periods of Jewish history as well as in contemporary times. Chief among the present ones in the Diaspora is the translation by liberal American Jewish denominations of humanistic values into the preeminent religious mandate of tikkun olam. Inasmuch as he appreciates this pristine ideal, as noted, he opposes its blanket imposition on the activities of the sovereign state. In point of fact, he sees the tension between "Jewish morality and 
sovereign morality" as fundamental to the conflict between American and Israeli Judaisms (Gordis 2019). Far more confident as he is in the long-term sustainability of Israeli Jewry than its North American counterpart, it is clear which of the two "moral" callings has the upper hand (Shain 2019).

Regarding Jewish religious life in the State of Israel, here too Shain engages aspects of religious ideals and practice. Their significance, however, is essentially political-how they reflect the centrality of sovereign Israel for Jewish life. Four topics exemplify this rendering: the concept of Israeli Judaism, conversion, Religious Zionists and theocracy, and the Haredim.

Citing the recent book Yahadut Yisra'elit (Israeli Judaism), co-authored by journalist Shmuel Rosner and demographer Camil Fuchs, both Israel-based, Shain highlights their argument that over its first seven decades Israel spawned a new type of Judaism that is rooted in statehood. While the majority of Israelis do not self-identify as observant (dati), they actually see Jewishness as fundamental to who they are. As such, unlike among North American Jews, where intermarriage has accelerated dramatically and participation in both private and public Jewish rituals has declined, there is considerable consensus among Israeli Jews regarding endogamy as well as the maintenance of certain religious elements, particularly Sabbath and holiday meals and rituals, and lifecycle ceremonies. To be sure, many chafe at the coercive aspects of Israeli public religion, but in areas where they have complete free choice, the majority integrate religious symbols and practices into their lives on a regular basis (Rosner and Fuchs 2018).

Shain does not explore the spiritual motivations that might be involved; rather, he emphasizes the role of religion as the common culture of the sovereign state. In the words of Rosner and Fuchs:

For most Jews in Israel, living in Israel defines being a good Jew....We just explained that most Israelis see themselves first and foremost as Jews. Now it becomes clear that for most Israelis to be a good Jew means to live in Israelto be an Israeli....In other words: to be first and foremost a Jew, one must first and foremost be an Israeli....Jewishness and Israeliness mix together into a new formula. There are parts that are exclusive to the observant, and others that are actually emphasized more among the nonobservant. But there is much that is shared by all, or almost all. These are the seeds of a renewed culture, Israeli Judaism....A culture in which to be a "good Jew" means both to "uphold holidays, ceremonies, and customs" and "to serve in the IDF [Israel Defense Forces]" or "to educate toward IDF service." (Rosner and Fuchs 2018, 82)

According to Shain, this novel hybrid formulation, which is so much a product of the sovereign reality, offers a fresh and secure path to the future for the Jewish religion. His reading, of course, assumes that such a civil construct is equivalent to a religious life. From a political perspective it certainly can be seen this way. Alternatively, if one perceives religion as more than a "movement" or cultural product, then Shain's conclusions here are less clear cut.

As to the highly contentious issue of conversion, Shain acknowledges the challenges and insult implicit in the lack of Israeli recognition of non-Orthodox change 
of status. Yet he highlights those studies that demonstrate that formal conversion has become far less of a barometer for inclusion within the State of Israel. Invoking the terminology put forward by political scientist Asher Cohen, Shain raises the fact that many Russian-speaking immigrants adopt the main features of Israeli Judaism without actually going through the rabbinate's giyur (conversion) process. Rather, these "non-Jewish Jews" attain their status through the "sociological conversion" that takes place when one lives over time in an Israeli-Jewish city or town, sends one's children to public school and then to the army, takes off on public holidays, and even adopts some of the rituals observed by most Israelis (Cohen 2005). Once again, for Shain, like Slezkine, religion is ultimately a political act.

This model of Israeli-Jewish identity, as Shain emphasizes, also sheds light on processes taking place among Israeli Arabs. According to a number of indicators, the longer they live under Israeli sovereignty, the more they adopt the major culture and reject efforts to cultivate institutions that are run in Arabic and are exclusive to them. That said, Shain rejects the possibility of an eventual "Herodization" or "political conversion" of the Arab population. Rather, he sides with the position that without a solution to the Palestinian issue, Israeli democracy will be unsustainable.

In respect to the future of the sovereign state, of equal concern to Shain are the impacts of two Jewish groups - both religious, the Dati-Leumi (National-Religious) and the Haredim (Israeli ultra-Orthodox). In each case, it is not their religious outlooks per se that spark his alarm but the impact that they can potentially have on the stability of the State, i.e., the ongoing strength of the Israelization process.

Regarding the National-Religious, the main issue for Shain is their growing influence on the IDF. If in the past the offspring of the secular elite dominated the key combat units and officers' ranks of the Israeli army, today many of the best and brightest prefer to serve in the 8200 division, the unit famous for cultivating some of the "start-up nation's" most advanced high-tech innovations and nurturing many successful entrepreneurs. During the past two decades, by contrast, soldiers from National-Religious Zionist homes-often graduates of pre-army mechinot [preparatory academies] programs that espouse a redemptive approach to mamlachtiyut [statism] in which army service reflects a religious imperative-have increasingly populated crack units and reached high-ranking positions (Fischer 2011; RosmanStollman 2014). Shain is deeply concerned about the potential for this sector to advance theocratic goals through its military prowess. All the same, he is relatively confident that — as demonstrated during the 2005 withdrawal from Gaza - their allegiance to the authority of the sovereign state will hedge against such a scenario (C. Waxman 2008).

As to the Haredim, Shain is far more alarmed. For unlike their Zionist religious cohorts, "[t]he animosity of many within Haredi society to sovereignty and to the modern values of the State of Israel is a time bomb" (Shain 2019, 281). This negativity is reflected in attitudes towards army service and other state institutions or values, such as the courts, gender equality, secular education, and the ascendancy of allegiance to halakhah over state law. Combined with the demographic trends that forecast the ongoing massive growth of this population and the widespread poverty among many of its members, Shain sees a collective existential crisis in the making (Shain 2019, 297). 
In this light, he cites the work of Kimmy Caplan (2007), who has pointed to the "Haredization" of Israeli religious society that was manifested in particularly extreme geographical and cultural enclavism among some Haredi subgroups from the late twentieth century. Shain also notes that both Caplan (2007) and Benjamin Brown (2015), among others, have shown that counter trends among the Haredi sector have gained traction that are indicative of greater integration into broader Israeli life and less hostility toward the state than in the past.

Ultimately, however, for Shain the litmus test of any aspect of Israeli society, and, for that matter, contemporary Judaism, is its relationship to the sovereign center. Thus, in a telling apocalyptical description, he presents Haredi Judaism as the archetype of Diaspora Judaism — a "demonic" force that may yet undo the Israelization process:

In the struggle between modernity and halakhah, extreme factions have emerged in Israel that are reminiscent of the Judean Desert Sect, who were recorded in the Qumran (Dead Sea) Scrolls and enshrined in history as those whose struggle in the name of religious purity against the Hasmonean state led to bloodshed. It is likely that history shall not repeat itself and such scenarios are one-time events, but it is hard to refrain from gazing once in a while in that direction. (Shain 2019, 297)

Shain indicates his awareness that drawing such knee-jerk doomsday parallels is an emotional response, yet he does not attend to the fact that his overall analysis of the Haredim digresses from the core argument of his book. Like other religious groups, he perceives them through a political lens. Yet his discussion of Haredim stands in contrast to his central Taylor-like focus on "conditions" and reactions to a new reality that avoids giving grades such as "more or less modern" or "more or less Zionist." Rather than the degree to which Israel's very existence shapes them and their responses, Haredim are evaluated based on their actual attitudes toward sovereignty and modernity. And indeed, due to Shain's perception that they represent the old "Diaspora"-inspired Judaism, they epitomize the antithesis to the Israeli century. Here, then, he falls into the old trap of "negation of the exile" as a foundation for Israel's centrality-precisely the formulation for which his core thesis offers a fresher and less partisan approach.

Indeed, it would appear that Shain's anxiety over Haredi influence is so entrenched that even when he presents striking examples of the transformational impact of Israeli sovereignty on this sector, he abandons the sanguinity that typifies every other instance of Israelization in the book. "The cardinal question for the future of the State and Israeli society," he avers, "is to what degree the Israelization of both Israel-based and American Haredim will eventually lead to a Haredization of Israel. This scenario... will not only undermine the freedom that characterizes the State but sovereignty itself" (Ibid., 38).

\section{The World of Contemporary Lived Judaism}

Until this point I have engaged critically with some of the key ideas and dissections that appear prominently in Shain's forceful tome. The parallel drawn with Taylor's A Secular Age (2007) emphasizes the novelty of Shain's model that 
argues for Israel's centrality to contemporary Jewish life based on its impact on Jews rather than the degree to which they support it or move there. Furthermore, I have examined more closely some of his main discussions of religion and religious groups, highlighting his political perception that homes in on the ways that specific factions and their ideals manifest or contest the realities of an entrenched and secure sovereign Israeli state.

I will now raise relevant examples from key Jewish religious trends that challenge aspects of Shain's core proposal. This succinct encounter with major components of contemporary Judaism offers a framework for examining the Israelization thesis from the perspective of lived religion (Hall 1997). Therefore, three phenomena that have strong visibility and bearing on Judaism outside of Israel are introduced as litmus tests: liberal (non-Orthodox) Judaism, the ChabadLubavitch Hasidic movement, and religious feminism. Each of these have representations in Israel, yet the first is primarily Diaspora-focused, while the others reveal global or transnational characters. My questions, then, are whether these instances also fit Shain's Israelization model such that their core existences are framed by the "conditions of experience" emanating from the reality of the State of Israel. Do these key manifestations of twenty-first century Judaism provide compelling evidence regarding the degree to which the condition of Israeli sovereignty, as defined by Shain, is or is not central to their current characters?

\section{Liberal (non-Orthodox) Judaism}

On May 19, 2019, Elliot Cosgrove, a keen observer of contemporary Jewish life and rabbi of New York's Park Avenue Synagogue, a prominent Manhattan Conservative synagogue with a 1700 family membership (Ghert-Zand 2018), published an op-ed article that seemingly both encapsulated and buttressed Shain's thesis:

These days, American Jews no longer debate who wrote the Bible. Instead, we argue about Israel. Israel is what brings us together and what tears us apart. We work to keep our relationship with Israel strong and are anxiety-ridden at signs of its weakening. We fear for our children's encounters with anti-Zionism on campus, and we hope that they sign up for Birthright trips. The labels that delineate our denominations are no longer based on belief or observanceOrthodox, Conservative, Reform, Reconstructionist-but on our views about Israel: AIPAC, ZOA, JVP, J-Street and the rest of the alphabet soup of Israel advocacy.

Despite the fact that we do not live, vote, serve in the military or pay taxes there, Israel has become the organizing principle and civil religion of American Jewry.

...While Jewish sovereignty is a cause for celebration, American Jews are still seeking to come to terms with this new reality. (Cosgrove 2019b) 
Cosgrove's comments reflect the "postdenominational" ambience of twentyfirst century American Judaism in which religious movement labels play less of a role in personal Jewish identification. But as Jack Wertheimer (2005) warned already in 2005, along with its many blessings a less contentious environment also brings with it an atmosphere of complacence. Enter Israel, a topic that increasingly divides American Jews and, in the process, elicits considerable passion on all sides.

Cosgrove, however, laments this condition because he perceives it as a deflection-a way to avoid addressing the core existential issues for American Jews:

Clearly, it is easier to take someone to task for their views on Israel than [sic] it is to come face-to-face with the withering of Jewish identity in one's children and grandchildren. If Jews spent less time attacking each other on Israel and more time building Jewish identity, devoted fewer resources to supporting the extremes of the Israel debate and more to making Jewish day school education, camping and synagogue life affordable, American Jewry would be in better shape, and so would our relationship with Israel.

Why do American Jews talk about Israel so much? Because it is easier than turning the lens on the endangered condition of our Judaism.

(Cosgrove 2019b)

Shain would likely argue that this scenario is by no means a matter of collective avoidance. Rather, it reflects the natural, one might even say deterministic, consequence of the progressive process of Israelization. In the Israeli century, the theological and ideological debates that once dominated the religious engagements of the American Jew have been upstaged by the transformed "conditions of experience" associated with rooted sovereignty.

Indeed, in his brief discussions of the relationships of the Conservative and Reform movements toward Israel, Shain emphasizes the fact that each see maintaining a campus in Jerusalem as a reflection of the criticality of the Jewish state to their values. This, he notes, is an exceptionally profound statement when coming from the Reform movement, whose leadership initially opposed Zionism and for many years expressed considerable ambivalence. Moreover, the fact that these constituencies have become so vigilant in protesting Israel's exclusive recognition of Orthodox standards of conversion, marriage, divorce, and rabbinic qualifications only testifies, in the eyes of Shain, to the elevated role that Israel plays in their Jewish self-understandings.

Yet Cosgrove's (2019b) protest suggests that gauging what epitomizes people's Jewishness primarily based on what side they take on a particularly contentious issue is not the only way nor the most accurate one, for such passion when unaccompanied by rigorous activism is "easy" and is not necessarily the central element of their Jewish connection. In this context, Werthheimer's The New American Judaism (2018), a 2018 National Jewish Book Award winner, points to an alternative perspective to that of Shain's regarding the religious nexus of nonOrthodox American Jews. 
Like Cosgrove, Wertheimer notes that other than Israel, "[i]t's hard to think of anything that arouses more passion and continuing concern" (Wertheimer 2018, 200). He also recognizes the sharp declines in non-Orthodox synagogue membership and in membership in other established Jewish organizations since the late twentieth century. Coupled with the steady increase in households with at least one Jewish parent that do not bring their children up as Jews, these measurements testify to a "recession" in American Jewish life. That said, the downturn in numbers and focus on national frameworks and movements, according to Wertheimer, only offers a "partial accounting" of the current picture. To attain a fuller appreciation of the current trends, his research not only considered the results of major demographic studies but focused extensive attention on the lived religion of American Jews in the local spaces where it takes place. As a result, he identifies and describes in great detail many fresh forms of Jewish activism and populations that were once marginalized demonstrating "high levels" of engagement. While the offspring of Reform and Conservative Jews may not be brand loyal, a vigorous nucleus are investing in novel forms of Jewish religiousness-prayer, rituals, music, and text study. These phenomena, he argues, point to "a nascent revival of Jewish religious life... a spirit of innovation and tinkering is stimulating the creation of hybrid forms of religious identification. Once dismissed as passing fads on the periphery of Jewish life, unconventional approaches to Judaism now are flourishing - and increasingly influencing the core" (Ibid., 3).

Wertheimer also dedicates a few pages of his study to describe the way that over the past seven decades Israel-through its new holidays, Hebrew pronunciation, liturgical additions and tunes, placement of Israeli flags in synagogue sanctuaries, and more recently through the sense of delegitimization felt by many American Jews - has become a key element in Jewish religious experience. Unlike Shain, however, he is not convinced that Israel is or can serve as the foundational basis for American Judaism (Kelman and Baron 2019). Building on broader studies of American society that demonstrate the "declining influence of ethnicity," Wertheimer asserts that "peoplehood alone will not keep Jews engaged in Jewish life with any measure of intensity." Rather, "aside from anti-semitic persecution, nothing is likely to play a larger role in determining the future of Jewish life in this country than the lived religion of ordinary Jews" (Wertheimer 2018, 21).

The contrasting interpretations that divide Shain and Wertheimer may be attributed to their different fields of expertise: political science versus history and sociology of religion and religious movements. No doubt, their personal dispositions play a role as well-Shain within the spectrum of Israeli secular-Zionist society and Wertheimer as an active American Conservative Jew. Truly, the latter states openly from the outset to "have tried to find a sweet spot between a posture of Olympian detachment and of subjective opinion" (Ibid. 15). All the same, Wertheimer's focus on religious renaissance showcases the lacunae in Shain's analysis, for it challenges the notion that contemporary Judaism can be understood primarily through the "conditions of experience" arising from the ongoing development of the sovereign Jewish state. If anything, it buttresses Taylor's notion that the "conditions of experience" associated with secularization can lead to fresh and creative directions among those elements who seek to re-invigorate religious life (Taylor 2007, 3). Shain could 
retort that the search for novel religious expression lacks the potency and pervasiveness of the Israel factor. In fact, he could claim that these tendencies reflect a poor attempt by elite groups of liberal American Jews who are uncomfortable with Jewish sovereign power to produce viable and ultimately unsustainable substitute forms of identification. Yet it is highly-perplexing that in Shain's work, one that purports to offer the key to understanding contemporary Judaism, Wertheimer's book is cited only once, and only regarding the high rates of assimilation, lack of staunch commitment, and decline in American Jewish religious affiliation. A less selective reading would have forced Shain to come to terms with an entire scope of American Jewish religious experience that cannot simply be framed by the Israelization thesis. As Wertheimer explains, specifically in light of the recessional aspects that he fully concedes, "All the more remarkable, then, are the countervailing trends: several million Jews still claim to be adherents to the Jewish religion, attend some kind of religious services, continue to learn about their traditions, and invest themselves to an extent in the renewal of Judaism" (Werthheimer 2018, 5). ${ }^{4}$

\section{Chabad-Lubavitch}

One seemingly counterintuitive example of a postdenominational framework that has flourished in contemporary Jewish life is the Chabad-Lubavitch Hasidic movement. Its principal population maintains an ultra-Orthodox religious lifestyle that emphasizes strict adherence to Jewish law, limited exposure to secular learning, and chasteness and modesty. All this is predicated on deep allegiance to the mystical ideals of its late spiritual leader, Rabbi Menachem Mendel Schneerson, 1902-1994. Yet unlike the dominant enclavist approaches within the broader Hasidic and nonHasidic Haredi sectors, from the beginning of his reign as the Lubavitcher Rebbe in 1951, Schneerson encouraged his followers to focus on bringing nonobservant and alienated Jews closer to traditional Jewish practice and beliefs (Fishkoff 2003). Such "outreach" efforts, he proclaimed, were part of the redemptive process and crucial to ensuring the imminent arrival of the messiah (Loewenthal 1998). While the messianic theological underpinnings of contemporary Chabad activism that "fires its engines" has drawn intense criticism from some respected observers, this has not impeded its integration into the Jewish religious mainstream (Tworek 2019).

The pathbreaking character of Chabad Houses on college campuses and in highdensity Jewish populations was already evident during Schneerson's lifetime. Especially since his passing, however, the army of Chabad shluchim and shluchos-male

\footnotetext{
${ }^{4}$ By no means does Wertheimer ignore the decline in synagogue attendance and membership among non-Orthodox Jews nor the rising numbers of born Jews who no longer identify as such, which is documented rigorously in A Portrait of Jewish Americans (Pew Research Center 2013). Yet his analysis of the "Pew" questions and answers, along with the qualitative field data that he collected in parallel, indicates that these classic parameters should no longer serve as the exclusive indicators of religious involvement. This is exactly the point developed in the first two chapters of the book (pp. 25-66) that explore numerous alternative forums as well as key moments when contemporary non-Orthodox Jewish Americans seek out and cultivate religious meaning (Wertheimer 2018).
} 
and female emissaries - has grown exponentially as has its expansive global reach (Kraus 2007; Chabad centers and synagogue directory 2019). In fact, in much of Australia, the former Soviet Union, France, and even in parts of Great Britain, its institutions and their graduates have taken the reigns of religious leadership from the old established frameworks (Berman 2009; Apple 2012; Zelenina 2018). In North America too, a growing number of ostensibly Modern Orthodox synagogues are led by graduates of Lubavitcher yeshivas (Y. Sarna 2012). Moreover, Jews who grew up in non-Orthodox synagogues have increasingly been attracted to the Chabad House environments (A. Ferziger 2013). Initially, some Reform and Conservative rabbis expressed concern over this challenge to their constituencies. Over time many have learned to accept this reality and actually found ways to cooperate with local shluchim (Wertheimer 2018; Cosgrove 2019a).

To be sure, for some, Chabad's representatives and their venues are often perceived primarily as religious/kosher food service providers, with the most visible roles of the Chabad shliach being to demonstrate matzah baking, give out jelly donuts (sufganiyot) on Hanukkah, and provide inexpensive Jewish pre-schools or after-school experiences for the local Jewish population. Yet this is certainly not the case for those college students who choose the Chabad House as their primary, or one of their regular, Jewish spaces. Nor increasingly is it so in neighborhoods throughout North America, where Chabad succeeds in attracting regular attendees to their prayer services, Sabbath and holiday meals, lectures, and educational frameworks. Like many Orthodox rabbis, the shluchim may perform funerals, visit the sick, and supervise kosher facilities. What stands out, however, is that more so than the institutions of their traditionalist colleagues, the Chabad centers cater primarily to Jewish constituencies that in the past were more likely to affiliate with Reform, Conservative, and Reconstructionist congregations. ${ }^{5}$

Chabad's success among less observant and less-affiliated North American Jews has been attributed to the warmth and personal approach of its activists. To paraphrase the connection drawn by David Ellenson, the former president of the Hebrew Union College and a leading scholar of contemporary Judaism, in a public lecture, the Chabad House offered a comfortable and inviting space for a generation that Peter Berger described as "homeless" (Berger et al. 1974; Ellenson 2003). To be sure, the minimal mandatory financial demands-in comparison to established denominational frameworks - that Chabad institutions place upon those who attend their prayer gatherings, Sabbath meals, and educational and

\footnotetext{
5 During travels throughout North America, the United Kingdom, Western Europe, Australia, and Southeast Asia, I have witnessed this phenomenon repeatedly. One especially instructive exposure took place during a sabbatical stay in Charleston, South Carolina (Chabad of Charleston - Center of Jewish Life 2020). While there are three Orthodox synagogues that are located within walking distances of core members who observe Sabbath restrictions, the Chabad Center was established with a large parking lot and adjacent to a main suburban thoroughfare. Other than the schluchim who purchased a home close enough to walk, and like at most suburban Conservative and Reform synagogues, those who attend the Chabad Center's Sabbath and holiday events must arrive by car (Ramsey 2017). A more recent phenomenon that has not been studied rigorously is the increasing number of Chabad rabbis serving "mainstream" American Modern Orthodox congregations. Such affiliations are more common in the UK and Australia.
} 
social activities is also a compelling factor. As managers of self-supporting local entities, the emissaries certainly encourage giving among those who benefit from their services, but this is generally not a pre-condition for participation (Fishkoff 2003).

The success of Chabad may also be seen in the context of the overall postdenominational tenor of twenty-first century American Judaism. The same ambience that has inspired a variety of new independent religious initiatives has also made Chabad an appealing option for those seekers with whom its combination of Hasidic spirituality and sense of authenticity, together with non-coerciveness and relative tolerance of diversity, resonates. From this vantage point, Wertheimer foresees, "If large numbers of younger people raised in non-Orthodox movements come to regard Chabad centers as their synagogues, Chabad may become the new middle ground between Orthodoxy and liberal Judaism" (2018, 332-333 n.37).

Tellingly, Shain only mentions Chabad once in the entire book, noting it in the context of the connection between traditional Jewish messianism and the hope for renewal of Jewish sovereignty in Israel. Consistent with his political perspective, no attention is paid to the outsized role of Chabad Hasidism in the religious lives of many contemporary Jews throughout the world. Had he engaged this topic, he actually could have raised an interesting angle from which to support his central thesis. For on multiple levels the evolution of Chabad into a global phenomenon can be understood as a creative counter-response to the advent of the State of Israel.

Not only did the rise of Schneerson to the helm in 1951 practically parallel the establishment of the State of Israel, much of his revolutionary approach may be seen as aimed at providing a spiritual alternative to the focus on territorial sovereignty and the secular redemptive possibilities that it naturally inspires. His adaptation of military symbols, such as the "Tzivos Hashem" (army of God youth wing), "Mitzvah tanks," and even the unique Chabad male uniform, as well as the training of a crack force of "religious" ambassadors (shluchim), is also indicative of a counter-movement (Morris 1991; Kraus 2007; Heilman and Friedman 2010). Following Shain's focus on conditions and impact rather than agreement or support, and like the American novelists whose ambivalence toward the Jewish state actually caused them to "obsess" about the subject and explore alternative models, the rise of Chabad as a global Jewish presence also testifies to the Israel effect.

Furthermore, the ubiquitous Israeli post-army backpackers and adults who are constantly looking for new destinations to conquer are in part responsible for Chabad's expanding global reach in the twenty-first century. In certain major locations, there are actually two dedicated Chabad Houses, one for local families and another purely for Israelis, while in others-particularly in parts of Africa, South America, India, and Southeast Asia-the nearly exclusive clientele are Hebrewspeakers (Maoz and Bekerman 2009). There are also seasonal branches set up by young shluchim in training in parts of New Zealand and other popular extreme sports spots throughout the world. Chabad's role in facilitating Israeli travel is so critical that in some places the centers serve as unofficial consular offices with the shaliach and shlucha acting as the go-betweens with governments (Lev 2013). This has been especially so at times of natural disasters or when individual Israelis have been endangered or killed. As such, Chabad's profound growth since Schneerson's 
passing is acutely linked to the reality of the sovereign state and the Jewish population that it has produced.

Having acknowledged this connection, Shain's characterization of an "Israelization" of Judaism does not do justice to the profound global phenomenon of ChabadLubavitch. Inasmuch as it draws additional attention to the way a seemingly counterZionist movement actually built upon the reality of Jewish sovereignty, it ignores the pivotal role that the actual worship, study, Sabbath meals, and personal interface with the shluchim play for thousands of Jewish individuals throughout the world. For many of these geographically and religiously diverse Jews, such experiences and encounters form the foundation for their Jewish identities in a far more meaningful manner than their awareness of and reactions to the State of Israel.

It would appear, then, that the fast-growing global Chabad-style of Judaism epitomizes the opposite phenomenon from Shain's Israelization scenario. According to the Lubavitch worldview, the sovereign state has no inherent significance, and while there is a considerable Chabad presence in Israel, this is purely due to the critical mass of Jews who reside there. If anywhere, the Brooklyn headquarters at 770 Eastern Parkway and Schneerson's grave in Queens function as the center of gravity (M. Katz 2010). More fundamentally, the underlying effect of Chabad is to deemphasize territorial distinctiveness and focus on the personal religious identity of Jews throughout the world (Goldschmidt 2000). Indeed, Schneerson concentrated the redemptive process on raising the individual sparks in every Jew rather than on the physical ingathering of the Diaspora Jews or collective cohesion. This explains his focus on creating centers throughout the world: "[A]lthough we are at the last moments of exile, we must establish Chabad houses, establishments dedicated to Torah, prayer, and deeds of kindness in each and every place" (Schneerson 1987).

\section{Religious Feminism}

Among the many innovations of Chabad during the late twentieth century was the prominent roles of shluchos-female emissaries - in its outreach efforts. This was a sharp departure from the supportive, less visible positions within religious contexts that most Jewish women occupied historically (Schwartz 1995) and served as one of the models for other Haredi-oriented enterprises that arose subsequently (A. Ferziger 2015a). Schneerson was clearly aware of the overall transition in the status of women in American society that intensified dramatically from the 1960s, and the impetus for his initiatives was at its core pragmatic: to best achieve his goal of spreading Judaism to the less-affiliated (Kaufman 1995; Morris 1998). Despite intriguing parallels, this differed from the more evidently feminist ethos that inspired profound changes in the role of women in non-Orthodox and Modern Orthodox surroundings.

North American Judaism has been transformed since the 1970s by the forthright entrance of women into the public religious sphere (Antler 2018). Today full egalitarian participation and leadership has achieved consensus among the non-Orthodox and in most postdenominational settings (Schorr and Mendelson Graf 2016). Women have access to all facets of Jewish ritual and study (Millen 2004), so much 
so that gender-related issues have become the main dividing line between Orthodox and traditionalist-oriented postdenominational frameworks (Sales 2017). Not only have women's involvements expanded, but the change has impacted intellectual and theological directions through the new energies, diverse voices, and novel perspectives that have been introduced (Peskowitz and Levitt 1997; Plaskow 2009). The entrance of women into the religious sphere and their own self-awareness of their long history of secondary status has raised sensitivity among other populations that have been fully or partially excluded from partaking on equal terms in religious contexts due to disabilities, race, sexual orientation, and gender identification (Nadell 2019). Scholars, including feminist proponents, have also noted the concurrent decline in male synagogue involvement (Fishman and Parmer 2008). Following Taylor's point of departure, this too attests to the acute impression of the shift upon the environment.

Consistent with its more guarded approach to modifying Jewish law and custom, to date no Orthodox faction has embraced full egalitarianism. Nonetheless, involvement of women in aspects of Orthodox religious life that were previously officially closed to them has increased dramatically. The modifications and attendant internal clashes are most evident within the Modern Orthodox stream, which asserts the positive that can be achieved through appropriate integration of Jewish religious ideals with aspects of contemporary culture (A. Ferziger 2015b; Eleff 2016, 2020; J.S. Gurock 2009; C. Waxman 2017). The calls for major adjustments have been spearheaded since the late twentieth century by the Orthodox feminist movement, which developed in parallel to the growth of educational frameworks dedicated to expanding the level of women's expertise in traditional Jewish law and literature (IsraelCohen 2012).

In 1981, Blu Greenberg published On Women and Judaism: A View from Tradition, the first book-length articulation of a forthright Orthodox feminist program (Greenberg 1981). Beyond wrestling with ideological tensions, Greenberg advocated greater involvement by women in public ritual. Some of the ritual changes that she and her co-activists promoted found support among esteemed rabbis and scholars (Sperber 2010). Yet among the most influential rabbinical authorities within Modern Orthodoxy, many of these new efforts to alter traditional ritual practice were considered to be absolutely illegitimate and to pose great dangers (Frimer and Frimer 1998).

During the late twentieth and early twenty-first centuries, new female Orthodox religious leadership roles also emerged along with training programs to support them. Initially, these frameworks educated women to perform a variety of duties previously reserved for rabbis without assuming that official designation. In 2010, Rabbi Avi Weiss of New York, a foremost figure in the progressive wing of Modern Orthodoxy and founder of Yeshivat Maharat for women (In the News 2020), ordained a female student who completed the rabbinical requirements with the title rabba (a feminine form for rabbi) and was met with vocal rabbinical opposition (Weiss 2019). In 2015 and 2016, two coeducational Orthodox programs in Jerusalem took the further leap of ordaining its female graduates as full-fledged Orthodox "rabbis" (Borschel-Dan 2015). Subsequently, Orthodox synagogues hired alumnae of the new training frameworks to serve as clergypersons alongside their male 
rabbinical counterparts. As in the past, a vocal minority of respected rabbis and scholars gave their religious imprimatur to these developments, but the majority of Orthodox rabbis reacted less favorably. In February 2017, a legal ruling was adopted by the Orthodox Union (OU), the largest organization of Orthodox synagogues in North America, that prohibits formal women's ordination or functioning as clergy (A. Ferziger 2018).

While the liberal movements have embraced gender egalitarianism fully, the Modern Orthodox continue to wrestle and debate over one of this generation's most captivating collisions between long-held norms and contemporary values. Along with the ongoing and sometimes bitter conflicts, the powerful efforts on all sides to define religious ideals and standards in light of the current cultural revolution have facilitated considerable reflection and produced unprecedented ingenuity. Regardless of where one locates oneself along the religious spectrum, then, it is nearly impossible to engage actively with contemporary Judaism without encountering the transformation or ongoing existential tension that characterizes the meeting between gender egalitarianism and tradition. Its ramifications can be felt at home, school, camp, synagogue, and at lifecycle events.

As such, one is initially confounded: Why did Shain, who aimed to demonstrate the major transformation of contemporary "Judaism," ignore completely the emergence of religious feminism? But the answer is actually quite clear. Unlike the topics related to religion that he does touch upon-conversion, Jewish law and statehood, messianism, and the morality of power-the connection between sovereignty and the role of women in the religious sphere is less straightforward and does not have an unequivocal political element (Kwok and Donaldson 2015).

Here too, however, had he delved more extensively into the issue, Shain would have been able to point to the impact of Israel-based phenomena on the trajectory of change in the religious status of women. This is especially so regarding the Orthodox. The Israeli Reform (Yahadut Mitkademet) and Conservative (Masorti) movements have certainly adopted egalitarian policies, and numerous women rabbis serve in local congregational and organizational leadership positions. Nonetheless, it is quite clear that, for the most part, they followed the lead of their North American counterparts (Marx 2016). In fact, on gender issues the Masorti movement is more traditionalist than its overseas predecessor. ${ }^{6}$

As to the Orthodox, concurrent with the emergence in the 1980s of feminist activism in North America, key institutions that introduced high-level Talmud learning to women arose in Israel. Over the decades they have grown considerably, both in the number of students and in the programs they offer. The institutions now include advanced tracks that train women as authorities in specific aspects of Jewish law and dedicated tracks geared to those who come from abroad. The intellectual foundation provided by these Israeli frameworks played a critical part in stimulating the religious revisions that have gained currency in both hemispheres (Rosenberg 2012; Fuchs 2014). Jerusalem was also the venue that spawned the first Orthodox

\footnotetext{
${ }^{6}$ For example, some opinions of Masorti rabbis do not permit women to serve as witnesses for religious matters (The ordination of women as rabbis n.d.).
} 
"partnership" prayer services in which seating remains separated according to gender, but women chant the Torah for the congregation and lead some of the prayers. This ritual innovation then spread to other continents, especially North America (Partnership Minyanin 2020).

A counter argument to the seminal position of Israel in the evolution of Orthodox feminism is that most of the creators of the women's study centers and the founders of the partnership services were American-born immigrants or their children. After moving to Israel, they introduced ideas to which they had been exposed previously to their new environments.

My understanding is that notwithstanding the North American origins of religious feminism, the encounter of these themes with Israeli society was momentous and influenced its subsequent progression. Both the scholastic abilities of those for whom Hebrew was a mother tongue and the overall pioneering/start-up culture of contemporary Israel fused with the original concepts to produce a richer and oftentimes less inhibited, fresh religious trend. This, in turn, was brought back to the North American realm both through social media and the constant flow of Orthodox students between the two centers. Instead of mono-directional influence, then, religious feminism actually exemplifies the way that global realities produce transnational phenomena enabled by ongoing cross-fructification between distinct geographical spaces (van Elteren 2011).

Notably, Israeli Orthodoxy also evinces unique forms of religious feminism that have no equivalents in the Jewish Diaspora and are related directly to NationalReligious Zionist understandings of the meaning of statehood. Since 2010 there has been a monumental rise in the number of girls nurtured in Orthodox homes and educational institutions who are motivated to serve in the IDF, including combat positions, rather than follow the standard sectoral practice of performing voluntary civilian national service. This topic has generated heated rabbinical exchanges; some are concerned mainly about issues of chasteness and modesty, while others perceive this as part of an overall undermining of classical gender roles within Israeli society (A. Ferziger forthcoming). Regardless, here the interface between sovereignty and Jewish identity that Shain emphasizes is certainly at play, but serving in the Israeli army, again, is an issue that is territorially exclusive.

\section{Conclusion}

The above description and analysis of three powerful forces in twenty-first century Judaism attest to a more complex world Jewish dynamic than that put forward in Shain's cogently argued and provocative monograph. To be sure, over seven decades of Jewish statehood have impacted profoundly foundational aspects of Jewish life and distinctiveness both in Israel and throughout the globe. Astonishing advances in communication and transportation technologies have also facilitated more persistent interfaces between Jews throughout the world and Israeli society. The results have been alternatively a deeper sense of connection or mounting alienation. Yet there are major aspects of what Jews perceive as experiencing Judaism and reflections of identification that are not derived from nor determined by the conditions dictated by 
the ongoing existence and growth of the sovereign state. Of the examples assessed here, liberal Judaism remains a predominantly Diaspora phenomenon, Chabad highlights a distinctively non-territorial, globalized formulation of Judaism, and the evolution of religious feminism within Orthodoxy models a transnational religious product resulting from the back and forth interactions between committed Jewish populations in North America and Israel.

Beyond the specifics of each of the three cases considered, there is an underlying claim that I wish to advance: An account of Jewish life that relates to religion through a nearly exclusively political construct cannot offer a fundamental statement of the nature and trajectory, indeed transformation, of contemporary Judaism. At least until Taylor's secular age, most of Judaism's well-documented history presents as a hybrid "ethnic-church" (J. Sarna 2004). Together with specific varying historical and geographical contexts, Jewish lives were dictated by core theological principles and religio-legal statutes and customs. Even if other manifestations of Jewish identity have gained prominence in the past two centuries, religious behavior and beliefs remain rooted in the lives of many Jews, and some religious trends have demonstrated renewed vitality in the twenty-first century. Thus, I appreciate Shain's astute turn from adoption of values to foundational "conditions." Nonetheless, any attempt to characterize contemporary Judaism rigorously must delve deeply into the lived religion of Jews - as reflected in practice and/or religious experience. Without addressing analytically this core element, even the most thoughtful, paradigmchallenging perceptions are at best partial and have the capacity to distort the overall picture.

\section{Afterword: Covid-19 and Israelization}

This essay, as well as Shain's book which stimulated it, were prepared before the tragic pandemic of 2020 that has already caused so much death and suffering, and wreaked havoc on local and global economies. Its impact upon religious and cultural life has also been pervasive. While it is too early to detail its long-term effect on contemporary Judaism, based on what has happened so far, the theme of Israelization analyzed and critiqued above, offers a valuable perspective from which to consider evolving trends.

To date, contradictory tendencies have emerged. On one hand, the closing off of Israel to most foreign flights and overall sense that international travel will be severely limited for the foreseeable future, has already widened the chasm between American and Israeli Jews, challenging the "conditions" that placed Israel at the center of the Jewish globe. This was exacerbated by the contrast between the misfortune and trauma felt by leading American Jewish communities, as opposed to in Israel, where the spread of the virus was curtailed quickly and relatively few people died. On the other hand, the rapid adoption of Zoom and other media technologies has facilitated an unprecedented cottage industry of meetings, conferences, Jewish learning, and even collective prayer frameworks, that have flattened the globe. Jews from both sides of the ocean have come together on a more regular basis than ever 
before, as broad audiences gained novel exposures to scholars and thinkers based in multiple locales.

An additional novelty is recognition of the obsolescence of the old AmericaIsrael paradigm, whereby American Jews supported Israel in periods of danger, while Israelis felt little obligation to reach out to their foreign brethren in times of distress. In an unlikely about face, some American Jewish leaders have expressed a clear need for Israeli help and intervention, and especially after the local situation improved, multiple Israeli initiatives aimed at demonstrating solidarity and care have been organized.

None of these early reactions to the Corona crisis erase the discrepancies between American and Israeli Jewish experiences, including those aspects of lived religion highlighted in this article, nor do they guarantee the emergence of a permanent new normal. Yet they do heighten the prospect that the process of Israelization expounded by Shain, will gain further traction moving forward.

\section{References}

Abramson, Yehonatan. 2017. Making a homeland, constructing a diaspora: The case of Taglit-Birthright Israel. Political Geography 58: 14-23.

Ahren, Raphael. 2019. Hungary to open office with 'diplomatic status' in Jerusalem. The Times of Israel, February 19. Retrieved from https://www.timesofisrael.com/hungary-to-open-office-with-diplo matic-status-in-jerusalem. Accessed 24 May 2020.

Antler, Joyce. 2018. Jewish radical feminism: Voices from the women's liberation movement. New York, NY: NYU Press.

Apple, Raymond. 2012. The German rabbinate abroad-Australia. European Judaism 45 (2): 21-31.

Berger, Peter L. (ed.). 1979. The heretical imperative: Contemporary possibilities of religious affirmation. Garden City, NY: Anchor Press.

Berger. Peter L. 1999. The desecularization of the world: Resurgent religion and world politics. Washington, DC: Ethics and Public Policy Center; Grand Rapids, MI: William B. Eerdmans Publishing Company.

Berger, Peter L., Brigitte Berger, and Hansfried Kellner. 1974. The homeless mind: Modernization and consciousness. New York, NY: Vintage Press.

Berman, Elise. 2009. Voices of outreach: The construction of identity and maintenance of social ties among Chabad-Lubavitch emissaries. Journal for the Scientific Study of Religion 48 (1): 69-85.

Borschel-Dan, Amanda. 2015. At Orthodox women's ordination, preaching a halacha of compassion. The Times of Israel. Retrieved from http://www.timesofisrael.com/at-orthodox-womens-ordination -preaching-a-halacha-of-compassion. Accessed 24 May 2020.

Borschel-Dan, Amanda. 2018. Was there real communication at the 2018 GA? Yes, but not as part of the program. The Times of Israel. Retrieved from https:/www.timesofisrael.com/was-there-realcommunication-at-the-2018-ga-yes-but-not-as-part-of-the-program. Accessed 24 May 2020.

Bronfman, Charles. 2018. Charles Bronfman: On Israel's Missing Religious Tolerance. Forward. Retrieved from https://forward.com/opinion/400346/charles-bronfman-religious-tolerance-andrespect-rebalancing-the-jewish/. Accessed 28 Apr 2020.

Brown, Benjamin. 2015. Ha-Yahadut ha-haredit ve-ha-medinah. In Ke-she-ha-Yahadut pogeshet medinah, ed. Yedidia Z. Stern, Benjamin Brown, Kalman Neuman, Gideon Katz, and Nir Kedar, 79-271. Tel Aviv: Israel Democracy Institute/Yedioth Ahronoth. (Hebrew).

Caplan, Kimmy. 2007. Be-sod ha-siah ha-haredi. Jerusalem: Merkaz Zalman Shazar. (Hebrew).

Chabad centers and synagogue directory. 2019. Chabad.org. https://www.chabad.org/centers/default_cdo/ jewish/Chabad-Centers-and-Synagogue-Directory.htm. Accessed 29 Apr 2020.

Chabad of Charleston-Center for Jewish Life. 2020. https://www.jewishchs.org. Retrieved April 29, 2020. 
Chabon, Michael. 2007. The Yiddish policemen's union: A novel. New York, NY: HarperCollins Publishers.

Cohen, Asher. 2005. Yehudim lo-Yehudim: Zehut Yehudit Yisraelit ve-etgar harhavat ha-le'om ha-Yehudi. Jerusalem: Bar-Ilan University Law School/Hartman Institute. (Hebrew).

Contemporary Jewry. 2010. 30(2-3):141-319.

Cosgrove, Elliot J. 2019a. Do a mitzvah! Park Avenue Synagogue. https://pasyn.org/resources/sermons/ do-a-mitzvah. Accessed 29 Apr 2020.

Cosgrove, Elliot J. 2019b. When American Jews talk about Israel, we're really talking about ourselves. Forward. Retrieved from https://forward.com/opinion/424779/when-american-jews-talk-about -israel-were-really-talking-about-ourselves. Accessed 29 Apr 2020.

DellaPergola, Sergio. 2018. World Jewish population, 2017. In American Jewish year book 2017: The annual record of the North American Jewish communities, v. 117, eds. Arnold Dashefsky, and Ira M. Sheskin, 297-377. Cham, Switzerland: Springer. https://www.jewishdatabank.org/content/ upload/bjdb/World_Jewish_Population_2017_AJYB_DataBank_Final.pdf.

Efune, Dovid. 2015. In United Nations address, French philosopher Bernard-Henri Lévy calls for 'Muslim Nostra Aetate'. The Algemeiner. Retrieved from https://www.algemeiner.com/2015/12/20/ in-united-nations-address-french-philosopher-bernard-henri-levy-calls-for-muslim-nostra-aetate. Accessed 24 May 2020.

Eleff, Zev. 2016. Modern Orthodox Judaism: A documentary history. JPS Anthologies of Jewish Thought. Philadelphia, PA: The Jewish Publication Society; Lincoln, NE: University of Nebraska Press.

Eleff, Zev. 2020. Authentically Orthodox: A tradition-bound faith in American life. Detroit: Wayne State University Press.

Ellenson, David. 2003. The Reform rabbi and the assimilation crisis. Oral presentation at second annual conference of the Rappaport Center for assimilation research and strengthening Jewish Vitality, Bar-Ilan University, Ramat Gan.

Ferziger, Adam S. 2013. From Lubavitch to Lakewood: The "Chabadization" of American Orthodoxy. Modern Judaism: A Journal of Jewish Ideas and Experience 33 (2): 101-124.

Ferziger, Adam S. 2015a. Beyond Bais Ya'akov: Orthodox outreach and the emergence of Haredi women as religious leaders. Journal of Modern Jewish Studies 14 (1): 140-159.

Ferziger, Adam S. 2015b. Beyond sectarianism: The realignment of American Orthodox Judaism. Detroit, MI: Wayne State University Press.

Ferziger, Adam S. 2018. Female clergy in male space: The sacralization of the Orthodox rabbinate. The Journal of Religion 98 (4): 490-516.

Ferziger, Adam S. forthcoming. Sanctuaries and battlefields: Two worlds of Judaism and two Orthodox feminisms. Journal of Jewish Studies.

Ferziger, Jonathan, and Alisa Odenheimer. 2018. As the Gulf warms up to Israel, a synagogue grows in Dubai. Bloomberg Businessweek. Retrieved from https://www.bloomberg.com/news/articles/201812-05/as-the-arab-world-warms-to-israel-a-synagogue-grows-in-dubai. Accessed 24 May 2020.

Finkielkraut, Alain. 2004. In the name of the other: Reflections on the coming anti-Semitism. Azure: Ideas for the Jewish Nation 18: 21-33.

Fischer, Shlomo. 2011. Fundamentalist or romantic nationalist? Israeli modern Orthodoxy. In Dynamic belonging: Contemporary Jewish collective identities, ed. Harvey E. Goldberg, Steven M. Cohen, and Ezra Kopelowitz, 91-111. Oxford: Berghahn Books.

Fishkoff, Sue. 2003. The Rebbe's army: Inside the world of Chabad-Lubavitch. New York, NY: Schocken Books.

Fishman, Sylvia Barack, and Daniel Parmer. 2008. Matrilineal ascent/patrilineal descent: The gender imbalance in American Jewish life. Waltham, MA: Cohen Center for Modern Jewish Studies and Hadassah-Brandeis Institute.

Fox, Michael. 2005. Tevye and the 'Jewish century.' Haaretz. Retrieved from https://www.haaretz.com/ misc/article-print-page/1.4846284. Accessed 24 May 2020.

Frimer, Aryeh A., and Dov I. Frimer. 1998. Women's prayer services: Theory and practice. Tradition 32 (2): 5-118.

Fuchs, Ilan. 2014. Jewish women's Torah study: Orthodox religious education and modernity. New York, NY: Routledge.

Ghert-Zand, Renee. 2018. Doubling down on Israel, Park Avenue Synagogue brings huge group to Holy Land. The Times of Israel. Retrieved from https://www.timesofisrael.com/doubling-down-on-israe 1-park-avenue-synagogue-brings-huge-group-to-holy-land. Accessed 24 May 2020. 
Goldschmidt, Henry. 2000. Crown heights is the center of the world": Reterritorializing a Jewish Diaspora. Diaspora: A Journal of Transnational Studies 9 (1): 83-106.

Gordis, Daniel. 2019. We stand divided: The rift between American Jews and Israel. New York, NY: HarperCollins Publishers.

Greenberg, Blu. 1981. On women and Judaism: A view from tradition. Philadelphia: Jewish Publication Society.

Gurock, Jeffrey S. 2009. Orthodox Jews in America. Bloomington, IN: Indiana University Press.

Hall, David D. (ed.). 1997. Lived religion in America: Toward a history of practice. Princeton, NJ: Princeton University Press.

Halutz, Doron. 2015. The man who believes there's never been a better time to be Jewish. Haaretz. Retrieved from https://www.haaretz.com/jewish/.premium-there-s-never-been-better-time-to-bejewish-1.5352574. Accessed 24 May 2020.

Heilman, Samuel, and Menachem Friedman. 2010. The Rebbe: The life and afterlife of Menachem Mendel Schneerson. Princeton, NJ: Princeton University Press.

In the News. 2020. Maharat. https://www.yeshivatmaharat.org/press-releases-inthenews. Accessed 28 Apr 2020.

Israel-Cohen, Yael. 2012. Between feminism and Orthodox Judaism: Resistance, identity, and religious change in Israel. Leiden: Brill.

Katz, Jacob. 1982. From prejudice to destruction: Anti-Semitism, 1700-1933. Cambridge, MA: Harvard University Press.

Katz, Maya Balakirsky. 2010. The visual culture of Chabad. New York, NY: Cambridge University Press.

Kaufman, Debra R. 1995. Engendering Orthodoxy: Newly Orthodox women and Hasidism. In New world Hasidism: Ethnographic studies of Hasidic Jews in America, ed. Janet S. Belcove-Shalin, 135-160. Albany, NY: State University of New York Press.

Keinon, Herb. 2017. Netanyahu thanks Croatia for support in international forums. The Jerusalem Post. Retrieved from https://www.jpost.com/Israel-News/Netanyahu-thanks-Croatia-for-support-in-inter national-forums-479482. Accessed 24 May 2020.

Kelman, A.Y., and I.Z. Baron. 2019. Framing conflict: Why American congregations cannot not talk about Israel. Contemporary Jewry 39: 497-522.

Kelner, Shaul. 2010. Tours that bind: Diaspora, pilgrimage, and Israeli Birthright tourism. New York, NY: New York University Press.

Kraft, Dina. 2019. Deborah Lipstadt at Haaretz Judaism Conference: Israeli government 'sold out' memory of the Holocaust. Haaretz. Retrieved from https://www.haaretz.com/israel-news/watch-livehaaretz-s-judaism-israel-and-diaspora-conference-1.8056759. Accessed 24 May 2019.

Kraus, Yitzchak. 2007. Ha-shevi'i: Meshihiyut ba-dor ha-shevi'i shel Chabad. Tel Aviv: Yedioth Ahronoth. (Hebrew).

Kustanowitz, Esther D. 2019. Opening up American-Israeli conversations at Z3 Conference. Jewish Journal. Retrieved from https://jewishjournal.com/news/los_angeles/community/307430/opening-upamerican-israeli-conversations-at-z3-conference. Accessed 24 May 2019.

Kwok, Pui-Lan, and Laura E. Donaldson (eds.). 2015. Postcolonialism, feminism and religious discourse. New York, NY: Routledge.

Lazare, Daniel. 2005. The chosen people. The Nation. Retrieved from https://www.thenation.com/article/ chosen-people. Accessed 28 Apr 2020.

Lev, David. 2013. Ministry to Israelis abroad: Try Chabad for help. Arutz Sheva. Retrieved from http:// www.israelnationalnews.com/News/News.aspx/169310. Accessed 24 May 2020.

Levy-Paz, Gitit. 2016. Leumiyut Yehudit, Zionut u-mekomah shel Yisrael ba-mahshavah u-va-zehut haYehudit ha-Amerika' it al pi ha-roman "Igud ha-Shotrim ha-Yidim" shel Michael Chabon. Bi-Ferat u-bi-Khlal; al Yahadut, Ribonut, ve-Zehuyot Adam 1: 77-125.

Liebman, Charles S., and Steven M. Cohen. 1990. Two worlds of Judaism: The Israeli and American experiences. New Haven, CT: Yale University Press.

Litvak, Meir. 2006. The Islamic Republic of Iran and the Holocaust: Anti-Semitism and anti-Zionism. Journal of Israeli History 25 (1): 267-284.

Loewenthal, Naftali. 1998. Contemporary Habad and the paradox of redemption. In Perspectives on Jewish thought and mysticism, ed. Alfred L. Ivry, Elliot R. Wolfson, and Allan Arkush, 381-402. Amsterdam: Harwood Academic Publishers.

Maoz, Darya, and Zvi Bekerman. 2009. Chabad tracks the trekkers: Jewish education in India. Journal of Jewish Education 75 (2): 173-193. 
Marx, Dalia. 2016. Women rabbis in Israel. In The sacred calling: Four decades of women in the rabbinate, ed. Rebecca Einstein Schorr and Alysa Mendelson Graf, 279-293. New York: CCAR Press.

Melman, Yossi. 2010. Why the Mossad must remain an intelligence service for all Jews. Haaretz. Retrieved from https://www.haaretz.com/1.5134754. Accessed 24 May 2020.

Millen, Rochelle L. 2004. Women, birth, and death in Jewish law and practice. HBI Series on Jewish Women. Hanover, NH: Brandeis University Press/University Press of New England.

Mlotek, Avram. 2019. So tightly bound: A group of entrepreneurial rabbis looks to weave new ties between Israeli and American Jews. The New York Jewish Week. Retrieved from https://jewishweek.timesofisr ael.com/so-tightly-bound. Accessed 24 May 2020.

Morris, Bonnie J. 1991. The children's crusade: The Tzivos Hashem youth movement as an aspect of Hasidic identity. Judaism 40 (3): 333-343.

Morris, Bonnie J. 1998. Lubavitcher women in America: Identity and activism in the postwar era. Albany, NY: State University of New York Press.

Nadell, Pamela. 2019. America's Jewish women: A history from colonial times to today. New York, NY: W.W. Norton.

Niebuhr, Reinhold. 1932. Moral man and immoral society: A study in ethics and politics. New York, NY: Charles Scribner's Sons.

Partnership Minyanim. 2020. JOFA. Retrieved from https://www.jofa.org/partnership-minyans. Accessed 29 Apr 2020.

Peskowitz, Miriam, and Laura Levitt (eds.). 1997. Judaism since gender. New York, NY: Routledge.

Pew Research Center. (2013). A portrait of Jewish Americans: Findings from a Pew Research Center survey of U.S. Jews. Washington, DC: Pew Research Center. https://www.pewforum.org/2013/10/01/jewis h-american-beliefs-attitudes-culture-survey. Accessed 29 Apr 2020.

Pink, Aiden. 2019. Pittsburgh Jews ‘heartbroken’ after Poway synagogue shooting six months later. Forward. Retrieved from https://forward.com/fast-forward/423303/pittsburgh-jews-heartbroken-after-poway -synagogue-shooting-six-months. Accessed 24 May 2020.

Plaskow, Judith. 2009. Feminist theology. Jewish women: A comprehensive historical encyclopedia. https:// jwa.org/encyclopedia/article/feminist-theology. Accessed 29 Apr 2020.

Ramsey, Molly. 2017. Sharing Heritage. Charleston Magazine. Retrieved from https://charlestonmag.com/ features/sharing_heritage. Accessed 24 May 2020.

Ravid, Shlomi. 2018. Re-focusing Jewish peoplehood. eJewish Philanthropy. https://ejewishphilanthropy. com/re-focusing-jewish-peoplehood. Accessed 24 May 2020.

Rawidowicz, Simon. 1957. Babylon and Jerusalem: Towards a philosophy of Israel's wholeness. London: Ararat Publishing Society.

Rosenberg, Esti. 2012. The world of women's Torah learning-Developments, directions and objectives: A report from the field. Tradition 45 (1): 13-36.

Rosman-Stollman, Elisheva. 2014. For God and country? Religious student-soldiers in the Israel Defense Forces. Austin, TX: Center for Middle Eastern Studies at the University of Texas at Austin.

Rosner, Shmuel. 2018. Special election panel: Knesset member Meirav Ben-Ari and Amnon Lord. JPPI (The Jewish People Policy Institute). http://jppi.org.il/new/en/article/podcast/episodes/english-speci al-election-panel-knesset-member-ayelet-nahmias-verbin-and-professor-yossi-shain/\#.XdZmm1czbI U. Accessed 29 Apr 2020.

Rosner, Shmuel, and Camil Fuchs. 2018. Yahadut Yisra'elit: Diyukan shel mahapehah tarbutit. Tel Aviv: Dvir Books/The Jewish People Policy Institute. (Hebrew).

Sales, Ben. 2017. Egalitarian New York yeshiva teaches Torah to Jews in pews-Not future rabbis. Forward. Retrieved from https://forward.com/news/364896/egalitarian-new-york-yeshiva-teaches-torah-to-jewsin-pews-not-future-rabbi. Accessed 24 May 2020.

Sarna, Jonathan D. 2004. American Judaism: A history. New Haven, CT: Yale University Press.

Sarna, Yehuda. 2012. The end of the middle of the road: Re-envisioning modern Orthodoxy for the twentyfirst century. In The next generation of modern Orthodoxy, ed. Shmuel Hain and Robert S. Hirt, 332349. New York, NY: Yeshiva University Press.

Schneerson, Menachem Mendel. 1987. Sichos in English Volume 34. Brooklyn, NY: SIE Online version retrieved from https://www.sie.org/templates/sie/article_cdo/aid/2508118/jewish/Shabbos-ParshasVayigash-9th-Day-of-Teves-5747-1987.htm. Accessed 28 Apr 2020.

Schorr, Rebecca Einstein, and Alysa Mendelson Graf (eds.). 2016. The sacred calling: Four decades of women in the rabbinate. New York, NY: CCAR Press.

Schwartz, Shuly Rubin. 1995. "We married what we wanted to be": The rebbetzin in twentieth-century America. American Jewish History 83 (2): 223-246. 
Schweid, Eliezer. 1984. The rejection of the Diaspora in Zionist thought: Two approaches. Studies in Zionism 5 (1): 43-70.

Senor, Dan, and Saul Singer. 2009. Start-up nation: The story of Israel's economic miracle. New York, NY: Twelve.

Shain, Yossi. 2019. Ha-me'ah ha-Yisraelit: Ha-Yisraelizaziyah shel ha-Yahadut. Tel Aviv: Yedioth Ahronoth. (Hebrew).

Shmilovitz, Tzipi. 2018. Ha-Zioni ha-aharon. Yedioth Ahronoth. Retrieved from https://www.yediot.co.il/ articles/0,7340,L-5267258,00.html (Hebrew). Accessed 24 May 2020.

Slezkine, Yuri. 2019. The Jewish century [New Edition]. Princeton, NJ: Princeton University Press [original publication 2004].

Slezkine, Yuri, Sonja Luehrmann, and Todd Weir. 2018. A conversation with Yuri Slezkine. The Immanent Frame. Retrieved from https://tif.ssrc.org/2018/12/21/a-conversation-with-yuri-slezkine. Accessed 28 Apr 2020.

Sperber, Daniel. 2010. On changes in Jewish liturgy: Options and limitations. Jerusalem: Urim Publications. Taylor, Charles. 2007. A secular age. Cambridge, MA: The Belknap Press of Harvard University Press.

Tibon, Amir. 2019. Trump to speak at Adelson-backed Israeli-American Council conference. Haaretz. Retrieved from https://www.haaretz.com/us-news/.premium-trump-to-speak-at-israeli-american-counc il-annual-conference-1.8102289. Accessed 29 Apr 2020.

The ordination of women as rabbis. n.d. Responsa for today. https://responsafortoday.com/en/the-ordination -of-women-as-rabbis. Accessed 29 Apr 2020.

Tworek, Wojciech. 2019. Beyond hagiography with footnotes: Writing biographies of the Chabad Rebbe in the post-Schneerson era. AJS Review 43 (2): 409-435.

van Elteren, Mel. 2011. Cultural globalization and transnational flows of things American. In The systemic dimension of globalization, ed. Piotr Pachura, 139-162. Rijeka, Croatia: IntechOpen. https://www. intechopen.com/books/the-systemic-dimension-of-globalization/cultural-globalization-and-transnatio nal-flows-of-things-american. Accessed 29 Apr 2020.

Waxman, Chaim I. (ed.). 2008. Religious Zionism post disengagement: Future directions. New York, NY: Yeshiva University Press.

Waxman, Chaim I. 2017. Social change and halakhic evolution in American Orthodoxy. Liverpool: The Littman Library of Jewish Civilization/Liverpool University Press.

Waxman, Dov. 2016. Trouble in the tribe: The American Jewish conflict over Israel. Princeton, NJ: Princeton University Press.

Weiss, Avraham Avi. 2019. Journey to open Orthodoxy. Jerusalem: Urim Publications.

Wertheimer, Jack. 2005. All quiet on the religious front?: Jewish unity, denominationalism, and post denominationalism in the United States. New York, NY: American Jewish Committee.

Wertheimer, Jack. 2018. The new American Judaism: How Jews practice their religion today. Princeton, NJ: Princeton University Press.

Whitfield, Stephen J. 2006. Review of The Jewish century, by Yuri Slezkine. Modern Judaism 26 (3): 316-320.

Yehoshua, A. B. 2006. People without a land. Haaretz. Retrieved from https://www.haaretz.com/1.4905459. Accessed 29 Apr 2020.

Zelenina, Galina. 2018. Our community is the coolest in the world": Chabad and Jewish nation-building in contemporary Russia. Contemporary Jewry 38 (1): 249-279.

Publisher's Note Springer Nature remains neutral with regard to jurisdictional claims in published maps and institutional affiliations.

Adam S. Ferziger holds the S.R. Hirsch Chair in the Israel and Golda Koschitzky Department of Jewish History and Contemporary Jewry at Bar-Ilan University, Ramat Gan, Israel. He is a senior associate at the Oxford Centre for Hebrew and Jewish Studies, University of Oxford, UK, and is co-convener of the annual Oxford Summer Institute on Modern and Contemporary Judaism. His research focuses on Jewish religious movements and responses to secularization and assimilation in modern and contemporary North America, Israel, and Europe. His most recent books include authorship of Beyond Sectarianism: The Realignment of American Orthodox Judaism (2015), which was the winner of the 2015 National Jewish Book Award in American Jewish Studies, and co-editorship of Yitz Greenberg and Modern Orthodoxy: The Road Not Taken (2019). 